\title{
Persistent Defective Coupling of Dopamine-1 Receptors to G Proteins after Solubilization from Kidney Proximal Tubules of Hypertensive Rats
}

\author{
Anita Sidhu, Prayong Vachvanichsanong, Pedro A. Jose, and Robin A. Felder* \\ Department of Pediatrics, Georgetown University, Washington, DC 20007; and ${ }^{*}$ Department of Pathology, University of Virginia, \\ Charlottesville, Virginia 22908
}

\begin{abstract}
The natriuretic effect of dopamine-1 (DA-1) agonists is reduced in spontaneously hypertensive rat (SHR), partly because of defective DA-1 receptor-adenylate cyclase (AC) coupling in renal proximal convoluted tubules. To investigate this defective coupling, DA-1 dopamine receptors from renal proximal tubules were solubilized and reconstituted into phospholipid vesicles. The binding of DA-1-selective ligand [ ${ }^{125}$ I]SCH 23982 was specific and saturable, with no differences in receptor density or $K_{d}$ between SHR and normotensive rats (Wistar-Kyoto rats; WKY). Competition experiments of the reconstituted DA-1 dopamine receptors in WKY with a DA-1-selective agonist, SKF R-38393, revealed the presence of high- $\left(K_{h}=350 \pm 209 \mathrm{nM}\right)$ and low-affinity $\left(K_{1}=70,500 \pm 39,500 \mathrm{nM}\right)$ binding sites. 100 $\mu \mathrm{M} \mathbf{G p p}(\mathrm{NH}) \mathrm{p}$ abolished the agonist high-affinity sites, converting them to a low-affinity state $\left(K_{\mathrm{i}}=33,650 \pm 10,850 \mathrm{nM}\right)$. In SHR, one affinity site was noted $\left(K_{i}=13,800 \pm 500\right)$ and was not modulated by $\operatorname{Gpp}(\mathrm{NH}) \mathrm{p}\left(K_{\mathrm{i}}=11,505 \pm 2,295\right)$. The absence of guanine nucleotide-sensitive agonist high-affinity sites may explain the defective DA-1/AC coupling mechanism in the SHR. (J. Clin. Invest. 1992. 89:789-793.) Key words: radioligand binding $\bullet$ Wistar-Kyoto rats $\bullet$ dopamine-1 receptors $\bullet$ hypertension
\end{abstract}

\section{Introduction}

Dopamine exerts its biological effects through occupation of specific receptor subtypes. In the central nervous system and certain endocrine organs, the dopamine receptors are classified into the D-1 or D-2 subtypes on the basis of their ability to either stimulate or inhibit adenylate cyclase $(\mathrm{AC}),{ }^{1}$ respectively (1). These receptors have been cloned, including novel D-3, D-4, and D-5 dopamine receptors (2-10). In peripheral tissues, these receptors have been designated as DA-1 and DA-2 (11). The receptors in both the central nervous system and in peripheral tissues have marked similarities and some differences, the

Address reprint requests to A. Sidhu, Ph.D., Department of Pediatrics, 2PHC, Georgetown University, 3800 Reservoir Rd., NW, Washington, DC 20007.

Received for publication 26 December 1990 and in revised form 6 September 1991.

1. Abbreviations used in this paper: AC, adenylate cyclase; DA-1, dopamine receptor subtype 1; DPBS, Dulbecco's PBS; PCT, proximal convoluted tubules; SHR, spontaneously hypertensive rat; WKY, WistarKyoto rat (normotensive controls).

The Journal of Clinical Investigation, Inc.

Volume 89, March 1992, 789-793 most notable of which is the lower affinity of the renal dopamine receptor than of the brain dopamine receptor for dopaminergic drugs $(12,13)$. Indeed, the RNA for the cloned brain dopamine receptors has not been detected in the kidney, except (maybe) for the D-3 dopamine receptor (8).

The molecular mechanisms of dopamine action on DA-1 dopamine receptors in the kidney and the series of events that leads to physiological responses are beginning to be elucidated. In the kidney, there is evidence that dopamine, which is produced in the proximal tubule, increases sodium excretion by inhibition of $\mathrm{Na}^{+} / \mathrm{H}^{+}$antiport activity via cAMP (14). Dopamine also inhibits $\mathrm{Na}^{+} / \mathrm{K}^{+}$ATPase activity (15) and this effect is apparently mediated by protein kinase $C(16)$. In renal tissue, DA-1 agonists stimulate phospholipase $C(17,18)$.

We recently reported the existence of abnormalities in the renal dopaminergic system in the genetically hypertensive rat (spontaneously hypertensive rat; SHR) of the Okamoto Aoki strain (19). We also demonstrated that the natriuretic and the antinatriuretic effects of DA-1 agonists and antagonists, respectively, were reduced in the SHR but not in normotensive rat controls (Wistar-Kyoto rat; WKY) (20). In the SHR, both the potency of DA-1-selective agonists to compete for binding sites on the receptor and the ability of these agonists to stimulate $\mathrm{AC}$ were vastly diminished. The decreased ability of DA-1 agonists to stimulate $\mathrm{AC}$ activity was not due to a defective $\mathrm{AC}$ enzyme per se but rather to a defective DA-1 receptor-AC coupling mechanism (19). To investigate the mechanism for the defective DA-1 dopamine receptor in the SHR and to develop a cell-free system $(21,22)$ in which these mechanisms can be studied, we decided to analyze the guanine nucleotide-sensitive agonist high-affinity state of the receptor, which represents the activated receptor. We report that coupling of solubilized and reconstituted DA-1 dopamine receptors to $G$ proteins is deficient in SHR, but not in WKY, as evidenced by a complete lack of agonist high-affinity sites.

\section{Methods}

Materials. The DA-1-selective agonist SKF R-38393 and the DA-1-selective antagonist SCH 23390 were from Research Biochemicals Inc. (Natick, MA), Gpp(NH)p was from Boehringer Mannheim Corp. (Indianapolis, IN), and [ ${ }^{125}$ I]SCH 23982 was from New England Nuclear (Boston, MA). Sodium cholate, collagenase (type IV), crude phospholipids (type VII), and polyethyleneimine were purchased from Sigma Chemical Co. (St. Louis, MO), whereas SM-2 Bio-Beads were from Bio-Rad Laboratories (Richmond, CA). Dulbecco's PBS (DPBS) was purchased from Gibco Laboratories (Grand Island, NY). All other reagents were of the highest purity commercially available. 20-wk-old WKY and SHR (Okamoto-Aoki strain) were purchased from Taconic Farms, Inc., (Germantown, NY).

Membrane preparation. Renal cortical tubules enriched with proximal tubules were prepared as previously described, with modifications 
(23). In brief, the rats were anesthetized with pentobarbital $(50 \mathrm{mg} / \mathrm{kg}$ i.p.) and the kidneys exposed via a midline abdominal incision. A polyethylene catheter was inserted into the abdominal aorta just above the bifurcation into the iliac arteries. A direct blood pressure recording was obtained to verify the elevated systolic arterial pressure in the SHR $(185-210 \mathrm{mmHg})$ and normal pressure in the WKY $(135-145 \mathrm{mmHg})$. The kidneys were perfused with $25 \mathrm{ml}$ of $\mathrm{Ca}^{2+}$-free PBS, $\mathrm{pH} 7.4$, with collagenase ( $30 \mathrm{mg}$, Sigma type IV). The kidneys were then excised and the cortex isolated from the medulla. The cortical tissue, which was minced to a fine paste, was passed successively through a series of stainless steel sieves (Newark Wire Cloth Co., Newark, NJ) (in order: 212,85 , and $75 \mu \mathrm{m}$ ). The tubules (from the $85-\mu \mathrm{m}$ sieve) were resuspended in ice-cold DPBS and allowed to settle by gravity for $30 \mathrm{~min}$. The resulting pellet contained mainly proximal tubular cells, as ascertained by $\mathrm{AC}$ activation by DA-1 agonists and parathyroid hormone (19), alkaline and acid phosphatase determinations, and light microscopic examination (23). The tubules were free of glomeruli, as determined by acid phosphatase determinations and by light microscopic examination (23). In addition, most of the tubules took up fluorescein, which is characteristic of proximal but not distal tubular cells (24). Moreover, these tissues behaved in a fashion consistent with proximal convoluted tubules (PCT) obtained from WKY and SHR (19). The only other cortical tubule with AC-linked DA-1 dopamine receptor is present in the cortical collecting duct (12). However, the coupling of DA-1 dopamine receptors in the cortical collecting duct to AC is similar in WKY and SHR (25). Viability was determined by the failure of cells to take up $1 \%$ trypan blue (23).

The proximal tubules were homogenized at a protein concentration of $1 \mathrm{mg} / \mathrm{ml}$ in $10 \mathrm{mM}$ Tris- $\mathrm{HCl}, \mathrm{pH} 7.4$, containing protease inhibitors ( $1 \mathrm{mM}$ PMSF, $1 \mathrm{mM}$ EDTA, and $5 \mu \mathrm{g} / \mathrm{ml}$ each of leupeptin and pepstatin). Cellular debris and nuclei were pelleted at $270 \mathrm{~g}$ for $5 \mathrm{~min}$, and the resulting supernatant was centrifuged at $18,000 \mathrm{~g}$ for $20 \mathrm{~min}$ to pellet membranes. The crude membranes were washed once and were either used immediately or stored frozen in small aliquots at $-80^{\circ} \mathrm{C}$ in $10 \mathrm{mM}$ Tris $\mathrm{HCl}, \mathrm{pH} 7.4,5 \mathrm{mM} \mathrm{MgCl}$, and $250 \mathrm{mM}$ sucrose (26).

Solubilization and reconstitution. Proximal tubular membranes were solubilized by $1 \%$ sodium cholate, after pretreatment with $10 \mu \mathrm{M}$ SKF R-38393, essentially as described before for rat striatal D-1 dopamine receptors $(21,22)$. Briefly, membranes were suspended at $1-2$ $\mathrm{mg} / \mathrm{ml}$ in buffer A (50 mM Tris- $\mathrm{HCl}, \mathrm{pH} 7.4,120 \mathrm{mM} \mathrm{NaCl}, 5 \mathrm{mM}$ $\mathrm{KCl}, 2 \mathrm{mM} \mathrm{CaCl}$, and $1 \mathrm{mM} \mathrm{MgCl}$ ) in the presence of $10 \mu \mathrm{M} \mathrm{SKF}$ R-38393, a D-1 selective agonist. After $20 \mathrm{~min}$ at $37^{\circ} \mathrm{C}$, the membranes were centrifuged and suspended in solubilizing buffer $(50 \mathrm{mM}$ Tris$\mathrm{HCl}$, $\mathrm{pH} 7.4,5 \mathrm{mM} \mathrm{KCl}, 2 \mathrm{mM} \mathrm{CaCl}_{2}, 1 \mathrm{mM} \mathrm{MgCl}_{2}, 250 \mathrm{mM}$ sucrose, $1 \mathrm{mM}$ EDTA, $1.5 \mathrm{mM}$ PMSF, and $1 \mathrm{mM}$ DTT). In some studies, as noted in the legends to figures, $1 \mathrm{M} \mathrm{NaCl}$ was included in the solubilizing buffer. Sonicated phospholipids were added to a final concentration of $1.2 \mathrm{mg} / \mathrm{ml}$ and sodium cholate was added to a final concentration of 1\%. After a 15-20-min incubation on ice, the mixture was centrifuged at $31,300 \mathrm{~g}$ for $45 \mathrm{~min}$. The clear supernatant obtained after high-speed centrifugation was stored frozen in small aliquots at $-80^{\circ} \mathrm{C}(22,27)$.

For reconstitution of soluble DA-1 dopamine receptors into phospholipid vesicles, sonicated phospholipids $(20 \mathrm{mg} / \mathrm{ml})$ were readded to the soluble extract to a final concentration of $1.2 \mathrm{mg} / \mathrm{ml}$. Protease inhibitors ( $1 \mathrm{mM} \mathrm{PMSF}$ and $5 \mu \mathrm{g} / \mathrm{ml}$ each of leupeptin and pepstatin) were added directly to the soluble extracts before addition of phospholipids (26). Cholate was removed by the addition of moist SM-2 Bio-Beads $\left(1.2 \mathrm{~g} / \mathrm{ml}\right.$ of extract), and the mixture was shaken gently for $1 \mathrm{~h}$ at $4^{\circ} \mathrm{C}$. After the beads were allowed to settle, the turbid supernatant containing the proteoliposomes was aspirated and used directly in binding studies.

Radioligand binding assays. For saturation studies, it was essential to first reduce the specific activity of [ $\left.{ }^{125} \mathrm{I}\right] \mathrm{SCH} 23982$ to $220 \mathrm{Ci} / \mathrm{mmol}$ (dried before use) by diluting the stock radioligand 1:10 with its unlabeled isomer, SKF 103108-A. This permitted us to use concentrations of the ligand up to $50 \mathrm{nM}$ (final) in our incubation mixture. For competition studies, $1 \mathrm{nM}$ of the undiluted radioligand [ $\left.{ }^{125} \mathrm{I}\right] \mathrm{SCH} 23982$ (sp act $2,200 \mathrm{Ci} / \mathrm{mmol}$ ) was routinely used. The $\left[{ }^{125} \mathrm{I}\right] \mathrm{SCH} 23982$ binding to reconstituted receptors was assayed by filtration onto glass fiber filters $(28,29)$ pretreated with $200 \mu \mathrm{l}$ of ice-cold $0.3 \%$ polyethyleneimine solution. The binding assay was performed by using 25-50 $\mu \mathrm{l}$ of protein extract, $1 \mathrm{nM}\left[{ }^{125} \mathrm{I}\right] \mathrm{SCH} 23982$, and varying concentrations of D-1 dopamine-specific compounds. Nonspecific binding was determined with $10 \mu \mathrm{M} \mathrm{SCH} 23390$; all dilutions were done using buffer $B$ (50 mM Tris- $\mathrm{HCl}$, pH 7.4, $250 \mathrm{mM}$ sucrose, $5 \mathrm{mM} \mathrm{KCl}, 2 \mathrm{mM} \mathrm{CaCl}$, $1 \mathrm{mM} \mathrm{MgCl}, 1 \mathrm{mM} \mathrm{PMSF}$, and $5 \mu \mathrm{g} / \mathrm{ml}$ each of leupeptin and pepstatin) (26). After incubation at room temperature for $90 \mathrm{~min}$, binding was terminated by filtering the assay system onto glass fiber filters.

Other procedures. Protein was determined by the method of Lowry et al. (30). The computer-fitted program LIGAND (31) was used to analyze the binding data. In each case, a two-site model was considered to be a better fit according to the $F$ test at $P<0.05$. All values are summarized as means \pm SEM from two to six separate experiments.

\section{Results}

$\left[{ }^{125}\right.$ I]SCH 23982 binding to solubilized and reconstituted receptor preparations. We had earlier demonstrated that, on solubilization and reconstitution of brain D-1 dopamine receptors into phospholipid vesicles, the agonist high-affinity sites were potentiated and comprised $40-50 \%$ of the total receptor population $(21,22)$. These potentiated sites were due to increased coupling of receptor to $\mathrm{G}$ protein and were abolished by guanine nucleotide analogues. We decided to use a similar approach to study the guanine nucleotide-sensitive agonist highaffinity DA-1 sites in proximal tubules of normotensive WKY and hypertensive SHR rats.

DA-1 dopamine receptors from proximal tubules of WKY rats were extracted in the presence of $1 \mathrm{M} \mathrm{NaCl}$ and reconstituted into phospholipid vesicles, as described under Methods. The binding of the DA-1 dopamine-selective ligand [ $\left.{ }^{125} \mathrm{I}\right] \mathrm{SCH}$ 23982 to the reconstituted DA-1 dopamine receptors was specific and saturable (Fig. 1). Specific binding represented the bulk of total binding; nonspecific binding, defined as binding in the presence of $10 \mu \mathrm{M}$ of the DA-1 receptor-selective antagonist SCH 23390, was between 25 and $40 \%$ of total binding. Scatchard analysis (Fig. 1, inset) of the saturation data revealed that the ligand bound to a single site with an apparent $K_{\mathrm{d}}$ of $15.3 \pm 8.5 \mathrm{nM}$ and a maximum specific binding $\left(B_{\max }\right)$ of $663.0 \pm 142.3 \mathrm{fmol} / \mathrm{mg}$ of protein, which represents a slight enrichment over the PCT membranes of WKY rats $(479.1 \pm 22.2$ $\mathrm{fmol} / \mathrm{mg}$ protein) (19). This increase in specific activity suggests a partial purification of the DA-1 dopamine receptors on solubilization, possibly because of loss of cellular proteins. The results also suggest that this method of solubilization and reconstitution is well suited for extracting DA-1 dopamine receptors from PCT.

Similar results were also obtained with DA-1 dopamine receptors extracted from proximal tubular membranes of the SHR (Fig. 2). Accordingly, after solubilization and reconstitution of SHR receptors, the Scatchard analysis (Fig. 2, inset) of the saturation data revealed a $K_{\mathrm{d}}$ of binding of $22.0 \pm 6.7 \mathrm{nM}$ and $B_{\max }$ of $730 \pm 95 \mathrm{fmol} / \mathrm{mg}$ protein, representing a slight increase in specific activity over the membrane-bound receptor $\left(601.0 \pm 91.3 \mathrm{fmol} / \mathrm{mg}\right.$ protein) (19). The $K_{\mathrm{d}}$ values of [ $\left.{ }^{125} \mathrm{I}\right] \mathrm{SCH}$ 23982 binding to reconstituted DA-1 dopamine receptors was only 0.4-2-fold increased compared with the membranebound receptors in both WKY and SHR, where values of $10.9 \pm 1.3$ and $10.7 \pm 0.9 \mathrm{nM}$, respectively, were reported (19). These decreases in $\left.{ }^{125} \mathrm{I}\right] \mathrm{SCH} 23982$ binding affinity may be reflective of specific environmental requirements that have been disrupted on solubilization $(21,22)$. 


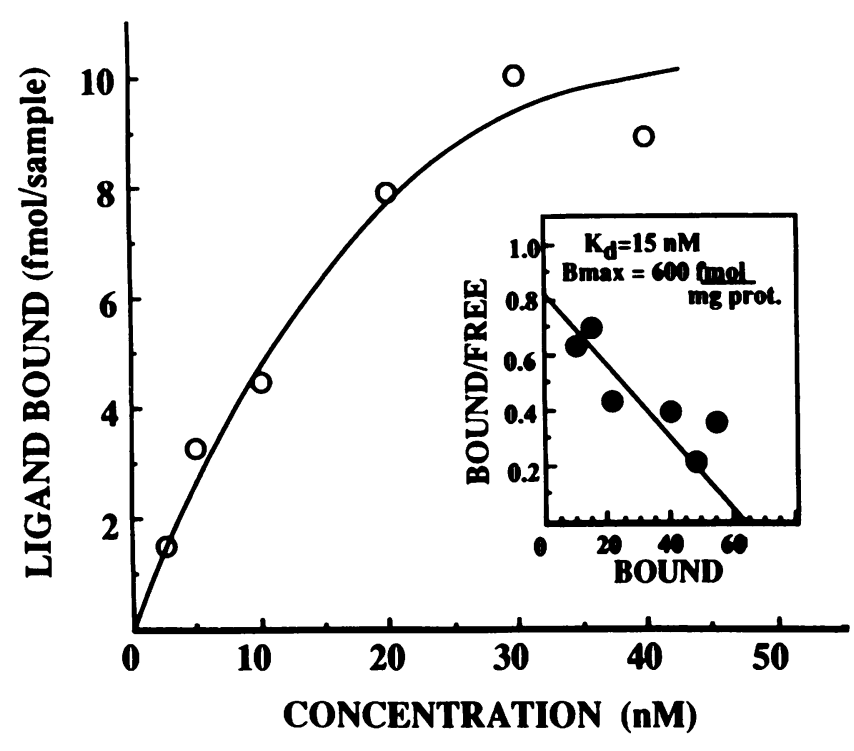

Figure 1. Concentration dependence of $\left[{ }^{125} \mathrm{I}\right] \mathrm{SCH} 23982$ binding to reconstituted DA-1 dopamine receptors extracted from the proximal tubules of WKY rats, in the presence of $1 \mathrm{M} \mathrm{NaCl}$. Proteoliposomes containing the reconstituted DA-1 receptors ( $25 \mu \mathrm{g}$ of protein/assay) were incubated in triplicate with increasing concentrations of the radioligand (sp act $220 \mathrm{Ci} / \mathrm{mmol}$ ) for $90 \mathrm{~min}$ at room temperature. Specific binding was obtained by subtracting nonspecific binding from the total binding, and the data were analyzed by a Scatchard plot (inset). The amount of bound and free ligand was calculated in femtomoles and nanomolar, respectively. The data are from a representative experiment.

Agonist competition of reconstituted DA-1 dopamine receptors of WKY. DA-1 dopamine receptors of WKY were extracted with sodium cholate and reconstituted into phospholipid vesicles; competition curves were obtained with SKF

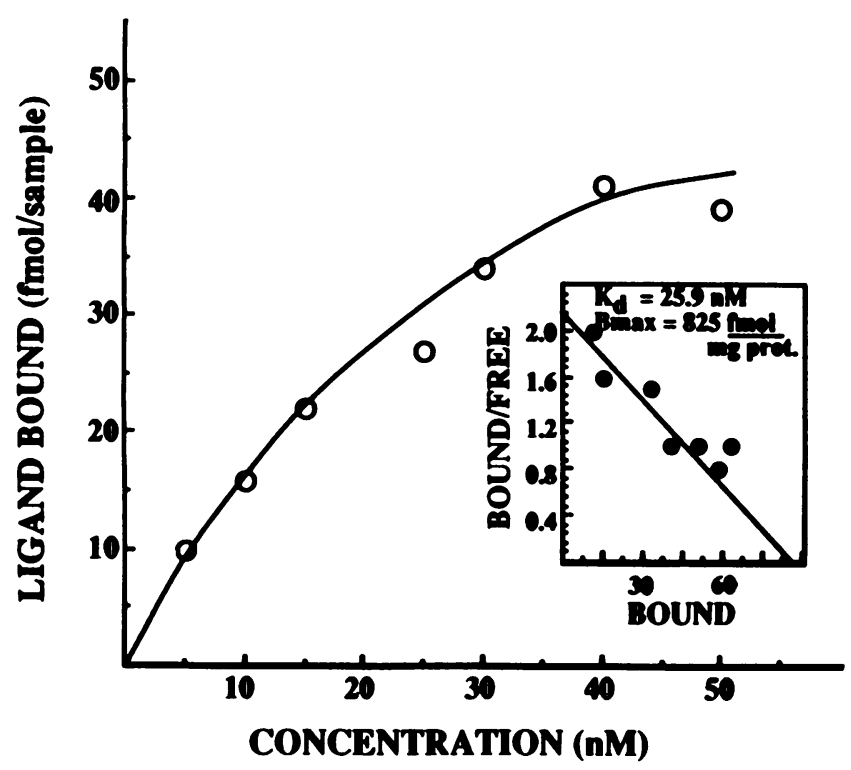

Figure 2. Concentration dependence of [ $\left.{ }^{125} \mathrm{I}\right] \mathrm{SCH} 23982$ binding to reconstituted DA-1 dopamine receptors extracted from proximal tubules of SHR, in the presence of $1 \mathrm{M} \mathrm{NaCl}$. DA-1 dopamine receptors were extracted from proximal tubules of SHR and were assayed as described in the legend to Fig. 1. The data are from a representative experiment.
R-38393, the DA-1 receptor selective agonist. $\mathrm{NaCl}$ was omitted from the solubilizing buffers in these studies, since the presence of the salt may adversely affect the agonist-binding properties of the receptor (unpublished observations). As seen in Fig. 3 , the curves were shallow and fit best to a two-site model with a high-affinity site $\left(K_{\mathrm{h}}\right)$ of $350 \pm 209 \mathrm{nM}$ and a low-affinity site $\left(K_{1}\right)$ of $70,500 \pm 39,500 \mathrm{nM}$. Approximately $40 \pm 5.6 \%$ of the receptors were in the high-affinity state. These high-affinity sites of the receptors were due to coupling to $\mathrm{G}$ proteins. Thus, in the presence of $100 \mu \mathrm{M} \mathrm{Gpp}(\mathrm{NH}) \mathrm{p}$, the high-affinity sites were abolished and a single site corresponding to the low-affinity state of the receptor was obtained with a $K_{\mathrm{i}}$ of $33,650 \pm 10,850$ nM (Fig. 3 and Table I). Competition curves with the DA-1 dopamine-selective antagonist SCH 23390 were monophasic, with a $K_{\mathrm{i}}$ value of $731 \pm 130 \mathrm{nM}$ (Table I).

Absence of guanine nucleotide-sensitive agonist high-affinity sites in reconstituted DA-1 dopamine receptors from $S H R$. DA-1 dopamine receptors from proximal tubules of SHR were solubilized and reconstituted into phospholipid vesicles in the absence of sodium chloride. Agonist competition curves of these reconstituted receptors from SHR were monophasic, and the $K_{\mathrm{i}}$ of binding of SKF R-38393 was $13,800 \pm 500 \mathrm{nM}$, corresponding to the low-affinity state of the receptor (Fig. 4). Further, this affinity state was not due to coupling to $G$ proteins, since in the presence of $100 \mu \mathrm{M} \mathrm{Gpp}(\mathrm{NH}) \mathrm{p}$, the $K_{\mathrm{i}}$ was virtually unaffected (Table I). These data suggest that the SHR DA-1 dopamine receptor is unable to couple to $G$ proteins under the present experimental conditions. This aberrant coupling between receptor and $G$ protein occurs in conditions that pro-

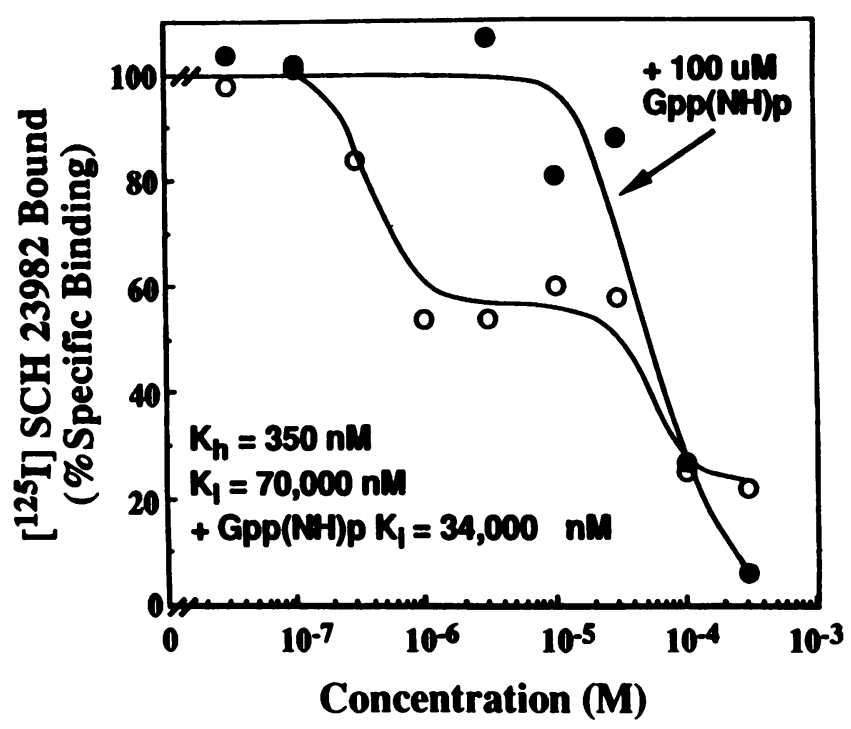

Figure 3. Effect of $\mathrm{Gpp}(\mathrm{NH}) \mathrm{p}$ on agonist competition for $\left[{ }^{125} \mathrm{I}\right] \mathrm{SCH}$ 23982 binding to reconstituted DA-1 dopamine receptors from proximal tubules of WKY rats. DA-1 dopamine receptors from proximal tubules of WKY rats were solubilized in the absence of any $\mathrm{NaCl}$. After reconstitution into phospholipid vesicles, the receptors were incubated at room temperature for 90 min with $1 \mathrm{nM}\left[{ }^{125} \mathrm{I}\right] \mathrm{SCH} 23982$ (sp act $2,200 \mathrm{Ci} / \mathrm{mmol}$ ) and increasing concentrations of the agonist SKF R-38393, in the absence $(0-0)$ or presence $(\bullet-\bullet)$ of $100 \mu \mathrm{M} \mathrm{Gpp}(\mathrm{NH}) \mathrm{p}$. Total binding was determined in the absence of any drug, whereas nonspecific binding was in the presence of $10 \mu \mathrm{M}$ SCH 23390. After accounting for nonspecific binding, the specific counts at each drug concentration were expressed as percentage of total specific binding. The data are from a representative experiment. 
Table I. Agonist and Antagonist $K_{i}$ s for Reconstituted DA-1 Dopamine Receptors from Proximal Tubules of WKY and SHR

\begin{tabular}{llcc}
\hline $\begin{array}{l}\text { Source of } \\
\text { receptors }\end{array}$ & Competing drug & Without Gpp(NH)p & With Gpp(NH)p \\
\hline & & \multicolumn{2}{c}{$n M$} \\
WKY & SKF R-38393 & $350 \pm 209\left(K_{\mathrm{h}}\right)$ \\
& & $70,500 \pm 39,500\left(K_{1}\right)$ & $33,650 \pm 10,850$ \\
WKY & SCH 23390 & $731 \pm 130$ & ND \\
SHR & SKF R-38393 & $13,800 \pm 500$ & $11,505 \pm 2,295$ \\
SHR & SCH 23390 & $620 \pm 142.0$ & ND \\
\hline
\end{tabular}

DA-1 dopamine receptors from proximal tubules of either WKY or SHR were solubilized in the absence of $\mathrm{NaCl}$, reconstituted into phospholipid vesicles, and incubated with $1 \mathrm{nM}\left[{ }^{125} \mathrm{I}\right] \mathrm{SCH} 23982$ and increasing concentrations of the drugs. After $90 \mathrm{~min}$ at room temperature, the incubation was terminated by filtering onto glass fiber filters. Values (nanomolar) represent the mean \pm SEM of two to four independent experiments.

$K_{\mathrm{h}}$, inhibition constant for the high-affinity site; $K_{1}$, inhibition constant for the low-affinity site; ND, not done.

mote such couplings in WKY (Fig. 3). The antagonist competition curves of SCH 23390 binding to reconstituted DA-1 receptors from SHR were monophasic, with $K_{\mathrm{i}}$ values of $620 \pm 142.0$ nM (Table I).

\section{Discussion}

We have earlier shown that DA-1 dopaminergic receptors from PCT of SHR are unable to stimulate AC (19). Furthermore, these receptors appear to have a lowered affinity for agonists compared with receptors from WKY rats. Photoaffinity labeling of DA-1 receptors from WKY and SHR, using the photoaffinity ligand $\left[{ }^{125} \mathrm{I}\right] \mathrm{MAB}$, did not reveal any differences in the

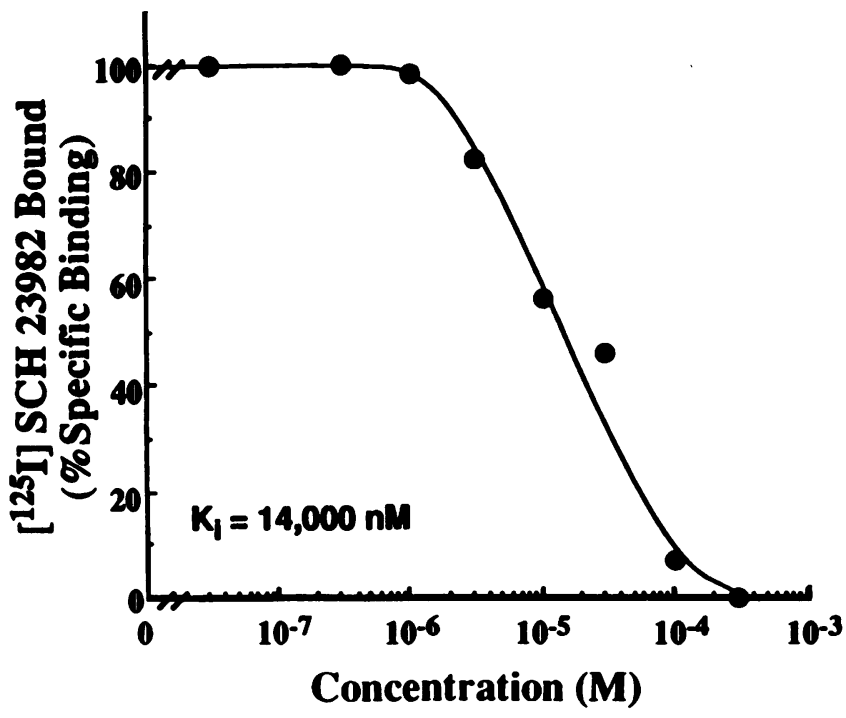

Figure 4. Ability of SKF R-38393 to compete for [ $\left.{ }^{125} \mathrm{I}\right] \mathrm{SCH} 23982$ binding to reconstituted DA-1 dopamine receptors from proximal tubules of SHR. DA-1 dopamine receptors from proximal tubules of SHR were solubilized in the absence of any $\mathrm{NaCl}$ and reconstituted into phospholipid vesicles. The binding assay was conducted as described in the legend to Fig. 3. The data are from a representative experiment. molecular weights or subunit composition of the labeled receptors (19). To further investigate the molecular mechanisms underlying the properties of DA-1 receptors in SHR rats, we decided to undertake the current study, using a model system that promotes receptor- $G$ protein couplings $(21,22)$. We found that renal receptors from the proximal tubules of WKY rats in a cell-free system existed in both high- and low-affinity states. The high-affinity sites were fully modulated by guanine nucleotides, suggesting that under the experimental conditions these sites were due to coupling between receptors and $G$ proteins. Under similar experimental conditions, however, the DA-1 dopamine receptors from proximal tubules of SHR were unable to couple to $G$ proteins; instead, there was only a single low-affinity, guanine nucleotide-insensitive site.

This inability of the receptor to couple to $G$ proteins in SHR may be due to defective receptor, defective $G$ protein, or both. Since we found earlier that the potency of DA-1 dopamine selective agonists to compete for binding sites on the receptor is diminished in SHR relative to WKY (19), it is possible that alterations in the molecular structure also exist at the agonist-binding site of the receptor. Further, the inability of receptor to couple to $G$ proteins in SHR suggests that alterations may exist in the third cytoplasmic loop of the receptor, the domain through which coupling to $G$ proteins occurs. While our data suggest that the defect may be at the receptor level, the possibility that the $G$ proteins themselves are defective cannot be ruled out, since receptor and cyclase coupling sites on the $G$ proteins are represented by distinct domains (33).

The inability of SHR DA-1 receptors to couple to G proteins may be of significance in understanding the mechanisms underlying certain types of hypertension. Interestingly, from radioligand binding studies, defects in D-1 dopamine receptors of the central nervous system have been associated with other pathophysiological conditions (34). It has been shown in postmortem Huntington's diseased putamen and amygdala that D-1 receptors are unable to couple to $G$ proteins, as evidenced by a complete lack of agonist high-affinity binding sites. From indirect evidence, others have also suggested that similar coupling defects may exist in schizophrenia and Huntington's disease, but not in Parkinson's or Alzheimer's disease (35). Although these studies warrant further investigation, it is tempting to speculate that defective $D-1 / D A-1$ receptor-G protein couplings exist in certain D-1 dopaminergic-linked diseases. On the basis of the presence of the DA-1 dopamine receptor defect in specific organs, and, indeed, in a specific nephron segment in spontaneous hypertension, it is possible that defects in discrete areas of certain organs may lead to different clinical manifestations.

We have recently demonstrated (36) that solubilized and reconstituted brain D-1 dopamine receptors were able to couple to exogenously added $G$ proteins after inactivation of endogenous $G$ proteins. A similar approach with DA-1 receptors from SHR rats may be useful to elucidate whether defective couplings are due to defective receptor, defective $G$ proteins, or both.

\section{Acknowledgments}

This work was partially supported by grants to A. Sidhu from the National Kidney Foundation and Alzheimer's Disease Association and by grants HL-23081 and DK-39308 from the National Institutes of Health. 


\section{References}

1. Kebabian, J. W., and D. B. Calne. 1979. Multiple receptors for dopamine. Nature (Lond.). 277:93-96.

2. Mosnma, F. J., Jr., L. D. McVittie, C. R. Gerfen, L. C. Mahan, and D. R. Sibley. 1990. Multiple $\mathrm{D}_{2}$ dopamine receptors produced by alternative RNA splicing. Nature (Lond.). 342:926-929.

3. Bunzow, J. R., H. H. M. Van Tol, D. K. Grandy, P. Albert, J. Salon, M Christie, C. A. Machida, K. A. Neve, and O. Civelli. 1988. Cloning and expression of a rat $\mathrm{D}_{2}$ dopamine receptor cDNA. Nature (Lond.). 336:783-787.

4. Dearry, A., J. A. Gingrich, P. Falardeau, R. T. Fremeau, Jr., M. D. Bates, and M. G. Caron. 1990. Molecular cloning and expression of the gene for a human $\mathrm{D}_{1}$ dopamine receptor. Nature (Lond.). 347:72-75.

5. Sunahara, R. K. H. B. Niznik, D. M. Weiner, T. M. Stormann, M. R. Brann, J. L. Kennedy, J. E. Gelernter, R. Rozmahel, Y. Yang, Y. Israel, et al 1990. Human dopamine $D_{1}$ receptor encoded by an intronless gene on chromosome 5. Nature (Lond.). 347:80-83.

6. Zhou, Q. Y., D. K. Grandy, L. Thambi, J. A. Kushner, H. H. M. Van Tol, R. Cone, D. Probnow, J. Salon, J. R. Bunzow, and O. Civelli. 1990. Cloning and expression of human and rat $\mathrm{D}_{1}$ dopamine receptors. Nature (Lond.). 347:76-79.

7. Monsma, F. J., Jr., L. C. Mahan, L. D. McVittie, C. R. Gerfen, and D. R. Sibley. 1990. Molecular cloning and expression of a $\mathrm{D}_{1}$ dopamine receptor linked to adenylyl cyclase activation. Proc. Natl. Acad. Sci. USA. 87:6723-6727.

8. Sokoloff, P., B. Giros, M. P. Martres, M. L. Bouthenet, and J. C. Schwartz 1990. Molecular cloning and characterization of a novel dopamine receptor $\left(D_{3}\right)$ as a target for neuroleptics. Nature (Lond.). 347:146-151.

9. Van Tol, H. H. M., J. R. Bunzow, H.-C. Guan, R. K. Sunahara, P. Seeman, H. B. Niznik, and O. Civelli. 1991. Cloning of the gene for a human dopamine $D_{4}$ receptor with high affinity for the antipsychotic clozapine. Nature (Lond.) 350:610-614.

10. Sunahara, R. K., H.-C. Guan, B. F. O’Dowd, P. Seeman, L. G. Laurier, G. $\mathrm{Ng}$, S. R. George, J. Torchia, H. H. M. Van Tol, and H. B. Niznik. 1991. Cloning of the gene for a human dopamine $D_{5}$ receptor with higher affinity for dopamine than $\mathrm{D}_{1}$. Nature (Lond.). 350:614-619.

11. Goldberg, L. I., J. D. Kohli, and D. Glock. 1986. Conclusive evidence for two subtypes of peripheral dopamine receptors. In Dopaminergic Systems and Their Regulation. G. N. Woodruff, J. A. Poat, and P. J. Roberts, editors. The MacMillan Press Ltd., London. 195-212.

12. Felder, R. A., C. C. Felder, G. M. Eisner, and P. A. Jose. 1989. The dopamine receptor in adult and maturing kidney. Am. J. Physiol. 257(Renal Fluid Electrolyte Physiol. 26):F315-F327, 1989

13. Andersen, P. H., J. A. Gingrich, M. D. Bates, A. Dearry, P. Falardeau, S. E. Senogles, and M. G. Caron. 1990. Dopamine receptor subtypes: beyond the $\mathrm{D}_{1} / \mathrm{D}_{2}$ classification. Trends Pharmacol. Sci. 11:231-236.

14. Felder, C. C., T. Campbell, F. Albrecht, and P. A. Jose. 1990. Dopamine inhibits $\mathrm{Na}^{+}-\mathrm{H}^{+}$exchanger activity in renal BBMV by stimulation of adenylate cyclase. Am. J. Physiol. 259(Renal Fluid Electrolyte Physiol. 28):F297-F303.

15. Aperia A., A. Bertorello, and I. Seri. 1987. Dopamine causes inhibition of $\mathrm{Na}^{+}-\mathrm{K}^{+}$-ATPase activity in rat proximal convoluted tubule segments. Am. J. Physiol. 252(Renal Fluid Electrolyte Physiol. 21):F39-F45.

16. Bertorello, A., and A. Aperia. 1989. $\mathrm{Na}^{+}-\mathrm{K}^{+}-\mathrm{ATP}$ ase is an effector protein for protein kinase $\mathrm{C}$ in renal proximal tubule cells. Am. J. Physiol. 256(Renal Fluid Electrolyte Physiol. 25):F370-F373.

17. Felder, C. C., M. Blecher, and P. A. Jose. 1989. Dopamine-1 mediated stimulation of phospholipase C activity in rat renal cortical membranes. J. Biol. Chem. 264:8739-8745.

18. Felder, C. C., P. A. Jose, and J. Axelrod. 1989. The dopamine-1 agonist, SKF 82526, stimulates phospholipase-C activity independent of adenylate cyclase. J. Pharmacol. Exp. Ther. 248:171-175.

19. Kinoshita, S., A. Sidhu, and R. A. Felder. 1989. Defective dopamine-1 receptor adenylate cyclase coupling in the proximal convoluted tubule from the spontaneously hypertensive rat. J. Clin. Invest. 84:1849--1856.

20. Felder, R. A., M. G. Seikaly, P. Cody, G. M. Eisner, and P. A. Jose. 1990 Attenuated renal response to dopaminergic drugs in spontaneously hypertensive rats. Hypertension. 15:560-569.

21. Sidhu, A., and P. H. Fishman. 1986. Solubilization of the D-1 dopamine receptor from rat striatum. Biochem. Biophys. Res. Commun. 137:943-949.

22. Sidhu, A. 1988. Solubilization and reconstitution of the D-1 dopamine receptor: potentiation of the agonist high-affinity state of the receptor. Biochemis try. 22:8768-8776.

23. Felder, R. A., M. Blecher, G. M. Eisner, and P. A. Jose 1984. Cortical tubular and glomerular dopamine receptors in the rat kidney. Am. J. Physiol. 246(Renal Fluid Electrolyte Physiol. 15):F557-F568.

24. Sullivan, L. P., J. A. Grantham, L. Rome, D. Wallace, and J. J. Grantham. 1990. Fluorescein tranport in isolated proximal tubules in vitro: epifluorometric analysis. Am. J. Physiol. 258(Renal Fluid Electrolyte Physiol. 27):F46-F51.

25. Ohbu, K., and R. A. Felder. 1990. Dopamine-1 stimulated adenylate cyclase (AC) in the microdissected cortical collecting duct of the Wistar Kyoto (WKY) and spontaneously hypertensive rat (SHR). Clin. Res. 38:429a. (Abstr.) 26. Sidhu, A. 1990. A novel affinity purification of D-1 dopamine receptor from rat striatum. J. Biol. Chem. 265:10065-10072.

27. Sidhu, A., R. A. Felder, P. A. Jose, and P. H. Fishman. 1990. Comparison of the central and renal dopamine-1 receptor. Am. J. Hypertens. 3:37s-39s

28. Sidhu, A., and J. W. Kebabian. 1985. An iodinated ligand identifying the D-1 dopamine receptor. Eur. J. Pharmacol. 113:437-440.

29. Sidhu, A. C., J. C. Van Oene, P. Dandridge, C. Kaiser, and J. W. Kebabian. 1987. ${ }^{125} \mathrm{I}-\mathrm{SCH} 23982$ : the ligand of choice for identifying the D-1 dopamine receptor. Eur. J. Pharmacol. 128:213-220.

30. Lowry, O. H., N. S. Rosebrough, A. L. Farr, and R. J. Randall. 1951 Protein measurement with Folin phenol reagent. J. Biol. Chem. 193:265-268.

31. Munson, P., and D. Rodbard. 1980. LIGAND: a versatile computerized approach for characterization of ligand binding systems. Anal. Biochem. 107:220-239.

32. Hess, E. J., and I. Creese. 1987. Biochemical characterization of dopamine receptors. In Dopamine Receptors. I. Creese and C. M. Fraser, editors. Alan R. Liss, Inc., New York. 1-27.

33. Raymond, J. R., M. Hnatowich, R. J. Lefkowitz, and M. G. Caron. 1990 Adrenergic receptors: models for regulation of signal transduction. Hypertension. 15:119-131.

34. De Keyser, J., J. P. De Becker, G. Ebinger, and G. Vauquelin. 1989. Coupling of $D_{1}$ dopamine receptors to the guanine nucleotide binding protein $G$ is deficient in Huntington's disease. Brain Res. 496:327-330, 1989.

35. Seeman, P., H. B. Niznik, H.-C. Guan, G. Booth, and C. Ulpian. 1989. Link between $D_{1}$ and $D_{2}$ dopamine receptors is reduced in schizophrenia and Huntington diseased brain. Proc. Natl. Acad. Sci. USA. 86:10156-10160.

36. Sidhu, A., M. Sullivan, T. Kohout, P. Balen, and P. H. Fishman. 1991. D dopamine receptors can interact with both stimulatory and inhibitory $\mathrm{G}$ Proteins. J. Neurochem. 57:1445-1451. 